\title{
Mechanical Stress Results in Immediate Accumulation of Glucosinolates in Fresh-Cut Cabbage
}

\author{
T. Požrl, B. Cigić, L. Demšar, J. Hribar, and T. Polak \\ Department of Food Science and Technology, Biotechnical Faculty, University of Ljubljana, Jamnikarjeva 101, SI-1111 Ljubljana, Slovenia \\ Correspondence should be addressed to T. Polak; tomaz.polak@bf.uni-lj.si
}

Received 19 May 2015; Revised 3 August 2015; Accepted 5 August 2015

Academic Editor: Mehmet Özturk

Copyright (C) 2015 T. Požrl et al. This is an open access article distributed under the Creative Commons Attribution License, which permits unrestricted use, distribution, and reproduction in any medium, provided the original work is properly cited.

\begin{abstract}
The intensity of mechanical stress and the temperature significantly affect the levels of individual and total glucosinolates in shredded white cabbage (cv. Galaxy). Mild processing (shredding to $2 \mathrm{~mm}$ thickness) at $8^{\circ} \mathrm{C}$ resulted in the accumulation of glucosinolates ( $40 \%$ increase) in comparison with unshredded cabbage, which was already seen 5 min after the mechanical stress. Severe processing (shredding to $0.5 \mathrm{~mm}$ thickness) at $20^{\circ} \mathrm{C}$, however, resulted in an initial $50 \%$ decrease in glucosinolates. The glucosinolates accumulated in all of the cabbage samples $30 \mathrm{~min}$ from processing, resulting in higher levels than in unshredded cabbage, except for the severe processing at $20^{\circ} \mathrm{C}$ where the increase was not sufficient to compensate for the initial loss. Glucobrassicin and neoglucobrassicin were the major glucosinolates identified in the cabbage samples. Mechanical stress resulted in an increase in the relative proportion of glucobrassicin and in a decrease in neoglucobrassicin.
\end{abstract}

\section{Introduction}

Sales of minimally processed vegetables are rapidly increasing, and these products have become an important convenience food $[1,2]$. However, the preparation of fresh-cut products causes damage to the plant tissue, resulting in a more perishable product that has a shortened shelf-life, compared to intact fruit and vegetables [3]. Higher respiration rates and transformation of many nutritionally important components result from the peeling, coring, cutting, shredding, and slicing of fruit and vegetables. These processing operations can lead to biochemical deterioration, surface browning, development of off-flavours, and texture breakdown, which often results in lower quality products $[4,5]$. Mechanical damage, on the other hand, can induce stress responses that result in the accumulation of desired bioactive compounds [6].

White cabbage is one of the few vegetables that can be stored until the new harvest, if this is done under the appropriate conditions, and it is an important source of plant bioactive compounds, especially in the winter months. A substantial proportion of cabbage consumption is as the fresh vegetable, as a salad, and its preparation involves intensive mechanical processing (cutting or shredding). Extensive tissue damage results in the decompartmentalisation of the cellular constituents and the mixing of enzymes and substrates. In cabbage and other plants of the Brassicaceae family, a typical, pungent, mustard-like aroma is almost immediately released. Volatile, unstable aglycones are formed after enzymatic hydrolysis of glucosinolates (GLS) by myrosinase, which then rearrange into a range of biologically active, and sometimes toxic, compounds, typically as isothiocyanates and nitriles $[7,8]$. These products have potent antimicrobial activities and are toxic to many insect herbivores $[9,10]$.

Historically, GLS have been regarded as antinutritional factors in human and animal foods [11]. Nevertheless, in more recent years, many nutritional and biochemical studies have indicated beneficial effects of GLS and their degradation products on human health, mostly due to their anticarcinogenic activities [12-14]. Vegetables with high GLS content and an acceptable taste are now desired on the market.

Mechanical stress results in not only the degradation of GLS but also the induction of the enzymes involved in their biosynthesis, which can arise through signalling molecules such as jasmonic acid, salicylic acid, and ethylene [15]. The total GLS content is significantly increased in chopped white 
cabbage and certain other Brassicaceae when they are left exposed to the air for two days, which is mostly due to the accumulation of indolyl GLS [16]. However, there is no information in the literature relating to the changes in GLS content immediately after processing and the influence of the intensity of the mechanical stress applied.

The aim of the present study was to evaluate the influence of intensity of mechanical damage and of the storage temperature of changes in GLS content in fresh-cut white cabbage. We shredded white cabbage and analysed the changes in GLS content at specific times. The influence of temperature and the severity of the processing were assessed immediately after shredding and after up to one day of storage in air.

\section{Material and Methods}

2.1. Materials. White cabbage (Brassica oleracea var. capitata L. forma alba) of cultivar Galaxy was obtained from Janež farm, Sneberje, Ljubljana, Slovenia. The cabbage was harvested approximately 180 days after transplantation with $48 \pm 3 \mathrm{~g} \mathrm{~kg}^{-1}$ soluble solids content. Samples were transported in the cold-storage chamber, where the cabbage heads were stored at a temperature of $0^{\circ} \mathrm{C}\left( \pm 1^{\circ} \mathrm{C}\right)$ and $97 \%$ relative humidity. Twenty-four hours before processing, the cabbage heads were conditioned in thermostated chambers with $97 \%$ relative humidity and at $8^{\circ} \mathrm{C}$ or $20^{\circ} \mathrm{C}$. The outer and damaged leaves were removed and the cabbages were processed as follows.

2.2. Experimental Design. The processing of the cabbages started with cutting them into quarters vertically and slicing out the core. The cabbage quarters were then shredded in the thermostated chambers, into slices of different thicknesses, using a kitchen electric slicing machine (Gorenje Food Processor S 201, Slovenia). Aliquots of shredded cabbage were then incubated under the appropriate conditions for predetermined times. All experiments were performed in independent triplicates (cabbage heads). Extraction and analysis of GLS in the individual samples (of independent triplicates) were performed in duplicate. The GLS content was expressed in $\mu \mathrm{mol} \mathrm{kg}$ fresh matter. The mass of the shredded cabbage samples was not decreased by more than $2 \%$ during storage, indicating only a small moisture loss.

Six cabbages were included in the experiment, three conditioned at $8^{\circ} \mathrm{C}$ and three at $20^{\circ} \mathrm{C}$. Part of each cabbage head was shredded into thick $2 \mathrm{~mm}$ slices, and the other part into thin $0.5 \mathrm{~mm}$ slices. Aliquots of $200 \mathrm{~g}$ of each shredding type were placed into separate jars, which were covered with perforated parafilm to allow the exchange of gases and to minimise water loss by evaporation. Notably here, the temperature of the whole and shredded cabbages was held constant during the whole experiment, at either $8^{\circ} \mathrm{C}$ or $20^{\circ} \mathrm{C}$. Sampling was carried out at the predetermined times of $5 \mathrm{~min}, 30 \mathrm{~min}, 2 \mathrm{~h}, 12 \mathrm{~h}$, and $27 \mathrm{~h}$ after shredding. Large patches of a mixture of internal and external leaves were used as the control, which was unshredded cabbage. The samples were then homogenised and subjected to analysis of GLS content by liquid chromatography-mass spectrometry (LCMS).
2.3. Determination of Glucosinolates Content. The GLS content was determined according to previously published procedures $[17,18]$, with modifications. Cabbage samples $(4 \pm$ $0.001 \mathrm{~g}$ ) were transferred into $10 \mathrm{~mL}$ methanol (Merck). The suspensions were homogenised (Ultra-Turrax T 25, with dispersing element S25N-18G, Janke \& Kunkel, IKA-Labortechnik, Germany) at 10,000 rpm for $60 \mathrm{~s}$ in an ice bath. The mixtures were then passed through filter paper (Sartorius 388 , FT-3-101-150), and aliquots of the filtrates (2 mL) were centrifuged at $16,000 \times \mathrm{g}$ for $10 \mathrm{~min}$ (Eppendorf microcentrifuge $5415 \mathrm{D})$. The supernatants were finally passed through syringe filters (0.45 $\mu \mathrm{m}$ PTFE, Rectek).

HPLC analyses were performed on an Agilent 1100 system, at a temperature of $25^{\circ} \mathrm{C}$. The analytical column was a Synergi Hydro-RP $(150 \mathrm{~mm} \times 2 \mathrm{~mm}$, particle size, $3 \mu \mathrm{m})$ from Phenomenex (Torrance, CA, USA). The separation was performed at a flow rate of $0.250 \mathrm{~mL} \mathrm{~min}^{-1}$ by gradient elution with $0.1 \%$ trifluoroacetic acid (Fluka) in water as solvent $\mathrm{A}$ and methanol (Merck) as solvent $\mathrm{B}$. The gradient programme was as follows: $100 \%-98.3 \% \mathrm{~A}, 0-5 \mathrm{~min} ; 98.3 \%-20 \% \mathrm{~A}, 5-$ $15 \mathrm{~min} ; 20 \%$ A, $15-17 \mathrm{~min} ; 20 \%-100 \%$ A, $17-20 \mathrm{~min} ; 100 \%$ A, 20-30 min. An injection volume of $10 \mu \mathrm{L}$ was used. GLS were identified and quantified using retention times and the spectra from certified reference materials (BCR-367R, Fluka) of known concentrations, run under the same conditions. The following GLS were quantified: sinigrin, glucobrassicin, neoglucobrassicin, 4-hydroxy-glucobrassicin, glucoalyssin, progoitrin, glucobrassicanapin, gluconapin, gluconasturtiin, and gluconapoleiferin.

The mass-selective detector (Waters, Quattro micro API) was equipped with electrospray ionisation using a cone voltage of $40 \mathrm{~V}$ and a capillary voltage of $3.6 \mathrm{kV}$ for negative ionisation of the analytes. The dry nitrogen was heated to $350^{\circ} \mathrm{C}$ and the drying gas flow was $400 \mathrm{~L} \mathrm{~h}^{-1}$. The cone gas flow (nitrogen) was $50 \mathrm{~L} \mathrm{~h}^{-1}$. The data were acquired in the selected ion mode (sinigrin, $m / z$ 358.20; glucobrassicin, $m / z$ 447.13; neoglucobrassicin, $m / z$ 477.19; 4-hydroxy-glucobrassicin, $m / z$ 463.19; glucoalyssin, $m / z$ 450.19; progoitrin, $\mathrm{m} / z$ 388.10; glucobrassicanapin, $\mathrm{m} / z$ 386.41; gluconapin, $\mathrm{m} / z$ 372.09; gluconasturtiin, $m / z$ 422.19; gluconapoleiferin, $m / z$ 402.41). The reproducibility of the GLS content was established by analysing the same (random) sample in six replicates; the coefficient of variation for all was lower than $6.4 \%$.

2.4. Statistical Analysis. The experimental data were evaluated statistically using the SAS/STAT programme. Basic statistical parameters were calculated by the MEANS procedure. The data were tested for a normal distribution and analysed by the general linear model. The statistical model included the main effects of shredding type (thin or thick) and storage time (unshredded, $5 \mathrm{~min}, 30 \mathrm{~min}, 2 \mathrm{~h}, 12 \mathrm{~h}$, and $27 \mathrm{~h}$ after shredding), interaction of type and time, and repetition (1-3). Means for the experimental groups were obtained using the Duncan procedure and were compared at the $5 \%$ probability level.

\section{Results and Discussion}

3.1. Content of Glucosinolates in Unshredded White Cabbage. GLS in all of the samples were analysed by LC-MS (Figure 1). 

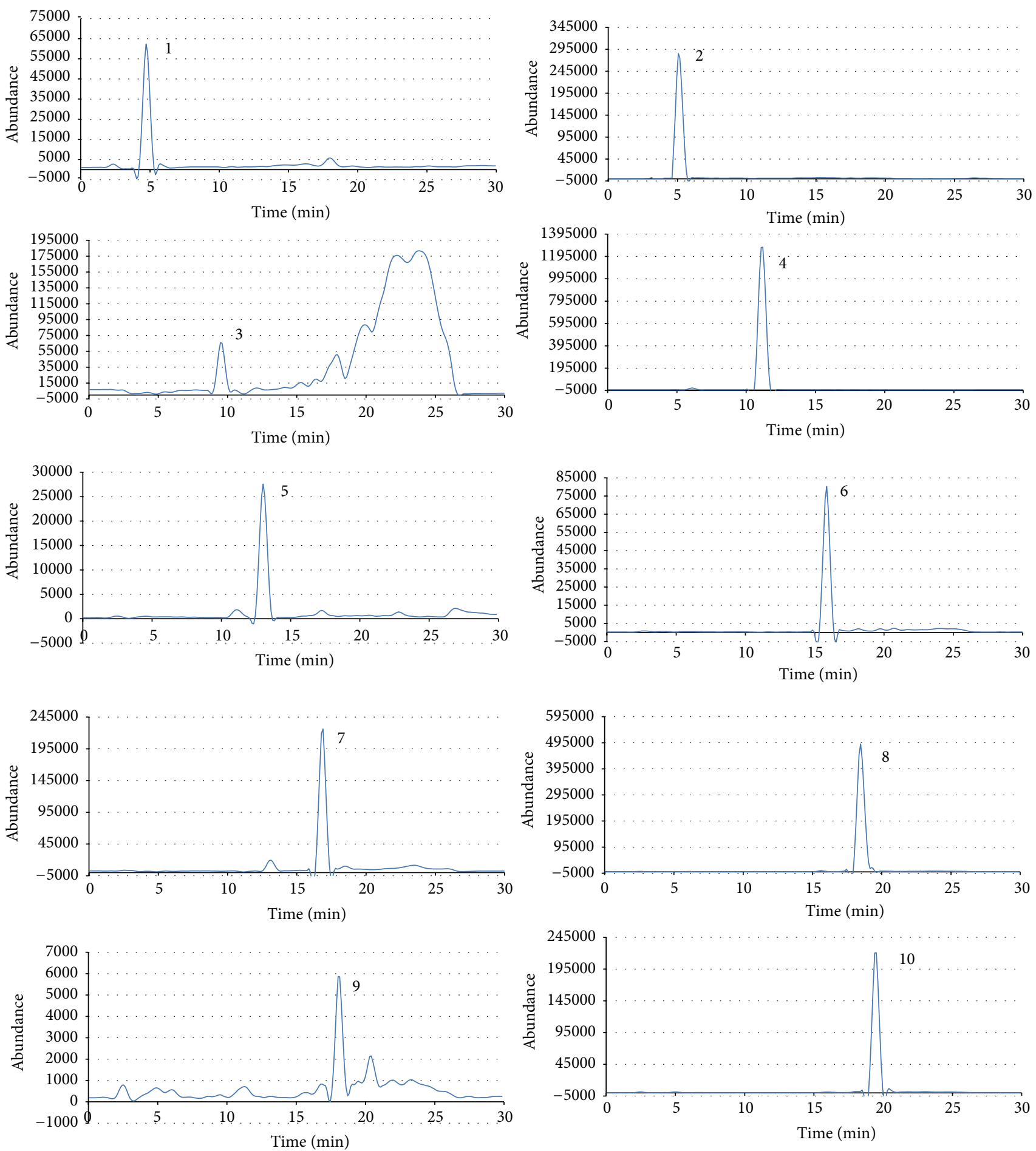

FigURE 1: LC-MS chromatogram of a cabbage sample stored for $12 \mathrm{~h}$ at $8^{\circ} \mathrm{C}$. Peak 1 , progoitrin, $m / z 388.10$; peak 2 , sinigrin, $m / z 358.20$; peak 3, gluconapoleiferin, $m / z$ 402.41; peak 4, gluconapin, $m / z$ 372.09; peak 5, glucoalyssin, $m / z$ 450.19; peak 6, 4-hydroxy-glucobrassicin, $m / z$ 463.19; peak 7, glucobrassicanapin, $m / z$ 386.41; peak 8, gluconasturtiin, $m / z 422.19$; peak 9, glucobrassicin, $m / z 447.13$; and peak 10 , neoglucobrassicin, $m / z 477.19$.

The average content of total GLS in the unshredded cabbage was $786 \pm 222 \mu \mathrm{mol} \mathrm{kg}^{-1}$ fresh weight $(\mathrm{FW})$. Two indolyl GLS, glucobrassicin $\left(435 \pm 159 \mu \mathrm{mol} \mathrm{kg}^{-1} \mathrm{FW}\right)$ and neoglucobrassicin $\left(188 \pm 69 \mu \mathrm{mol} \mathrm{kg}{ }^{-1} \mathrm{FW}\right)$, accounted for more than $75 \%$ of all of the GLS identified. Among the other GLS, only the content of the aliphatic GLS sinigrin (77 \pm $\left.35 \mu \mathrm{mol} \mathrm{kg}{ }^{-1} \mathrm{FW}\right)$ was high $\approx 10 \%$. Minor quantities of gluconasturtiin $\left(42 \pm 27 \mu \mathrm{mol} \mathrm{kg}^{-1} \mathrm{FW}\right)$, glucobrassicanapin 
TABLE 1: Effects of mechanical damage and measurement time on GLS content ${ }^{\mathrm{d}}$ in shredded cabbage after storage at $8^{\circ} \mathrm{C}$.

\begin{tabular}{|c|c|c|c|c|c|c|c|}
\hline \multirow{2}{*}{$\begin{array}{l}\text { Glucosinolates } \\
\left(\mu \mathrm{mol} \mathrm{kg}^{-1} \mathrm{FW}\right)\end{array}$} & \multirow{2}{*}{ Shredding } & \multicolumn{6}{|c|}{ Time } \\
\hline & & Unshredded & $5 \mathrm{~min}$ & $30 \mathrm{~min}$ & $2 \mathrm{~h}$ & $12 \mathrm{~h}$ & $27 \mathrm{~h}$ \\
\hline \multirow{2}{*}{ Glucobrassicin } & Thin & $411 \pm 190^{\mathrm{b}}$ & $473 \pm 40^{\text {aby }}$ & $570 \pm 82^{\mathrm{ab}}$ & $621 \pm 180^{\mathrm{a}}$ & $484 \pm 51^{\text {aby }}$ & $541 \pm 140^{\mathrm{ab}}$ \\
\hline & Thick & $411 \pm 190^{b}$ & $638 \pm 220^{\mathrm{ax}}$ & $631 \pm 130^{\mathrm{a}}$ & $641 \pm 120^{\mathrm{a}}$ & $655 \pm 110^{\mathrm{ax}}$ & $615 \pm 250^{\mathrm{a}}$ \\
\hline \multirow{2}{*}{ Neoglucobrassicin } & Thin & $160 \pm 51^{\mathrm{a}}$ & $114 \pm 11^{\text {by }}$ & $115 \pm 19^{\mathrm{bx}}$ & $116 \pm 13^{\text {by }}$ & $103 \pm 16^{\text {by }}$ & $103 \pm 16^{\mathrm{b}}$ \\
\hline & Thick & $160 \pm 51$ & $143 \pm 27^{\mathrm{x}}$ & $154 \pm 21^{\mathrm{y}}$ & $148 \pm 15^{\mathrm{x}}$ & $143 \pm 25^{\mathrm{x}}$ & $112 \pm 35$ \\
\hline \multirow{2}{*}{ Sinigrin } & Thin & $74 \pm 38^{\mathrm{b}}$ & $77 \pm 9^{\mathrm{b}}$ & $111 \pm 27^{\mathrm{a}}$ & $103 \pm 29^{\mathrm{ab}}$ & $88 \pm 25^{\text {aby }}$ & $110 \pm 38^{\mathrm{a}}$ \\
\hline & Thick & $74 \pm 38^{\mathrm{b}}$ & $120 \pm 59^{\mathrm{a}}$ & $135 \pm 47^{\mathrm{a}}$ & $126 \pm 47^{\mathrm{a}}$ & $134 \pm 43^{\mathrm{ax}}$ & $113 \pm 37^{\mathrm{a}}$ \\
\hline \multirow{2}{*}{ Gluconasturtiin } & Thin & $24 \pm 10^{\mathrm{b}}$ & $45 \pm 3^{\mathrm{a}}$ & $52 \pm 13^{\mathrm{a}}$ & $47 \pm 11^{\mathrm{a}}$ & $42 \pm 13^{\text {ay }}$ & $46 \pm 6^{\mathrm{a}}$ \\
\hline & Thick & $24 \pm 10^{\mathrm{b}}$ & $55 \pm 15^{\mathrm{a}}$ & $50 \pm 8^{\mathrm{a}}$ & $53 \pm 11^{\mathrm{a}}$ & $55 \pm 12^{\mathrm{ax}}$ & $50 \pm 16^{\mathrm{a}}$ \\
\hline \multirow{2}{*}{ Glucobrassicanapin } & Thin & $32 \pm 10$ & $21 \pm 6$ & $35 \pm 8$ & $31 \pm 13$ & $24 \pm 14$ & $31 \pm 12$ \\
\hline & Thick & $32 \pm 10$ & $25 \pm 13$ & $37 \pm 07$ & $33 \pm 11$ & $34 \pm 11$ & $28 \pm 05$ \\
\hline \multirow{2}{*}{ 4-Hydroxy-glucobrassicin } & Thin & $12 \pm 4$ & $8 \pm 2^{y}$ & $9 \pm 2^{y}$ & $10 \pm 2$ & $8 \pm 2^{y}$ & $9 \pm 3$ \\
\hline & Thick & $12 \pm 4$ & $11 \pm 2^{\mathrm{x}}$ & $12 \pm 1^{\mathrm{x}}$ & $11 \pm 2$ & $12 \pm 3^{\mathrm{x}}$ & $10 \pm 5$ \\
\hline \multirow{2}{*}{ Glucoalyssin } & Thin & $8 \pm 8$ & $16 \pm 5$ & $10 \pm 7$ & $12 \pm 8$ & $6 \pm 2$ & $4 \pm 1$ \\
\hline & Thick & $8 \pm 8$ & $9 \pm 8$ & $8 \pm 3$ & $6 \pm 4$ & $12 \pm 15$ & $6 \pm 4$ \\
\hline \multirow{2}{*}{ Progoitrin } & Thin & $4 \pm 2^{c}$ & $6 \pm 0^{\mathrm{b}}$ & $8 \pm 2^{\mathrm{a}}$ & $8 \pm 2^{\mathrm{ab}}$ & $6 \pm 2^{\text {by }}$ & $8 \pm 2^{\mathrm{ab}}$ \\
\hline & Thick & $4 \pm 2^{\mathrm{b}}$ & $9 \pm 2^{\mathrm{a}}$ & $10 \pm 2^{\mathrm{a}}$ & $9 \pm 3^{\mathrm{a}}$ & $10 \pm 2^{\mathrm{ax}}$ & $9 \pm 5^{\mathrm{a}}$ \\
\hline \multirow{2}{*}{ Gluconapin } & Thin & $0 \pm 0^{\mathrm{b}}$ & $1 \pm 0^{\mathrm{a}}$ & $1 \pm 0^{\mathrm{a}}$ & $1 \pm 1^{\mathrm{a}}$ & $1 \pm 0^{\mathrm{a}}$ & $1 \pm 1^{\mathrm{a}}$ \\
\hline & Thick & $0 \pm 0^{c}$ & $2 \pm 1^{\mathrm{a}}$ & $1 \pm 1^{\mathrm{ab}}$ & $1 \pm 1^{\mathrm{ab}}$ & $1 \pm 1^{\mathrm{ab}}$ & $1 \pm 1^{\mathrm{ab}}$ \\
\hline \multirow{2}{*}{ Gluconapoleiferin } & Thin & $1 \pm 1$ & $1 \pm 2$ & $0 \pm 1$ & $1 \pm 2$ & $1 \pm 1$ & $1 \pm 2$ \\
\hline & Thick & $1 \pm 1$ & $1 \pm 1$ & $0 \pm 1$ & $0 \pm 1$ & $1 \pm 1$ & $1 \pm 1$ \\
\hline \multirow{2}{*}{ Total } & Thin & $726 \pm 270$ & $743 \pm 82^{y}$ & $912 \pm 110$ & $950 \pm 230$ & $763 \pm 81^{y}$ & $855 \pm 200$ \\
\hline & Thick & $726 \pm 270^{\mathrm{b}}$ & $1010 \pm 240^{\mathrm{ax}}$ & $1040 \pm 110^{\mathrm{a}}$ & $1030 \pm 110^{\mathrm{a}}$ & $1060 \pm 130^{\mathrm{ax}}$ & $950 \pm 340^{\mathrm{ab}}$ \\
\hline
\end{tabular}

${ }^{\mathrm{d}}$ Content expressed as means \pm standard deviation. Means with different letters within a row (a, b, c) differ significantly ( $p \leq 0.05$; significance of difference between measuring times). Means with different letters within a column $(x, y)$ differ significantly $(p \leq 0.05$; significance of difference between shredding types). Thin, $0.5 \mathrm{~mm}$ slices; thick, $2 \mathrm{~mm}$ slices.

(22 $\left.\pm 15 \mu \mathrm{mol} \mathrm{kg}^{-1} \mathrm{FW}\right)$, 4-hydroxy-glucobrassicin (12 \pm $\left.3 \mu \mathrm{mol} \mathrm{kg}{ }^{-1} \mathrm{FW}\right)$, progoitrin $\left(8 \pm 6 \mu \mathrm{mol} \mathrm{kg}{ }^{-1} \mathrm{FW}\right)$, glucoalyssin $\left(5 \pm 2 \mu \mathrm{mol} \mathrm{kg}{ }^{-1} \mathrm{FW}\right)$, and gluconapoleiferin and gluconapin (under $1 \mu \mathrm{mol} \mathrm{kg}^{-1} \mathrm{FW}$ ) were also identified. A survey of the available data in the literature revealed that the content of total GLS in white cabbage can be within the span of one order of magnitude, as various studies have reported values in the range of $300 \mu \mathrm{mol} \mathrm{kg}{ }^{-1} \mathrm{FW}$ to $3000 \mu \mathrm{mol} \mathrm{kg}{ }^{-1} \mathrm{FW}$ $[16,19-23]$. Large variations in the content of total GLS and in their composition have been observed between different cultivars, geographical regions, times and conditions of storage, and sampling seasons and climates [21, 24, 25]. The data obtained in the present study are well within this range. A relatively large biological variability was reflected in the high coefficient of variation (30\%), as also observed in other studies. Appropriate control experiments are therefore extremely important when the influence of processing on GLS content is assessed.

3.2. Influence of Intensity of Shredding and Storage Temperature on Glucosinolate Content in White Cabbage, to $27 \mathrm{~h}$. The shredding intensity and temperature already had large effects on total GLS content within $5 \mathrm{~min}$ of processing.
Mild processing at $8^{\circ} \mathrm{C}$ (Table 1) resulted in an immediate and statistically significant increase in GLS content, as $\approx 40 \%$ higher levels of GLS were revealed in the processed cabbage, in comparison with the unshredded cabbage. When thin shredded cabbage that was processed at $8^{\circ} \mathrm{C}$ was analysed after $5 \mathrm{~min}$, no changes were seen for the total GLS. Processing of the cabbage at $20^{\circ} \mathrm{C}$ resulted in a lower total GLS content immediately after shredding (Table 2), in comparison with the same intensity of mechanical stress at $8^{\circ} \mathrm{C}$. A statistically significant decrease $(50 \%)$ was observed for the thin shredded cabbage $5 \mathrm{~min}$ after processing, whereas mild processing did not result in the higher total GLS content that was observed at the lower temperature.

Analysis of total GLS content $30 \mathrm{~min}$ after processing revealed that higher GLS contents were determined under all conditions, in comparison to the GLS content in cabbage determined after $5 \mathrm{~min}$. The increase in total GLS in the time range from $5 \mathrm{~min}$ to $30 \mathrm{~min}$ was the most pronounced and statistically significant for the thin shredded cabbage processed at $20^{\circ} \mathrm{C}(57 \%$, Table 2). Under the other three conditions (thick at $20^{\circ} \mathrm{C}$, thin at $8^{\circ} \mathrm{C}$, and thick at $8^{\circ} \mathrm{C}$ all at $30 \mathrm{~min}$ ), the total GLS accumulated in comparison with unprocessed cabbage was $22 \%$ more GLS for thick shredding 
TABLE 2: Effects of mechanical damage and measurement time on GLS content ${ }^{\mathrm{e}}$ in shredded cabbage after storage at $20^{\circ} \mathrm{C}$.

\begin{tabular}{|c|c|c|c|c|c|c|c|}
\hline \multirow{2}{*}{$\begin{array}{l}\text { Glucosinolates } \\
\left(\mu \mathrm{mol} \mathrm{kg}{ }^{-1} \mathrm{FW}\right)\end{array}$} & \multirow{2}{*}{ Shredding } & \multicolumn{6}{|c|}{ Time } \\
\hline & & Unshredded & $5 \mathrm{~min}$ & $30 \mathrm{~min}$ & $2 \mathrm{~h}$ & $12 \mathrm{~h}$ & $27 \mathrm{~h}$ \\
\hline \multirow{2}{*}{ Glucobrassicin } & Thin & $470 \pm 100^{\mathrm{ab}}$ & $259 \pm 71^{c y}$ & $429 \pm 43^{\mathrm{ab}}$ & $515 \pm 46^{\mathrm{a}}$ & $386 \pm 47^{\mathrm{b}}$ & $261 \pm 130^{\text {cy }}$ \\
\hline & Thick & $470 \pm 100$ & $554 \pm 190^{x}$ & $647 \pm 210$ & $817 \pm 260$ & $636 \pm 220$ & $607 \pm 190^{\mathrm{x}}$ \\
\hline \multirow{2}{*}{ Neoglucobrassicin } & Thin & $231 \pm 78^{\mathrm{a}}$ & $97 \pm 18^{\text {cy }}$ & $116 \pm 5^{\text {cy }}$ & $133 \pm 13^{\text {by }}$ & $71 \pm 9^{\text {cy }}$ & $82 \pm 36^{\mathrm{cy}}$ \\
\hline & Thick & $231 \pm 78^{\mathrm{a}}$ & $165 \pm 9^{b c x}$ & $184 \pm 16^{\mathrm{abcx}}$ & $207 \pm 25^{\mathrm{abx}}$ & $140 \pm 21^{\mathrm{cx}}$ & $217 \pm 33^{\mathrm{abx}}$ \\
\hline \multirow{2}{*}{ Sinigrin } & Thin & $83 \pm 34^{\mathrm{a}}$ & $33 \pm 6^{c}$ & $64 \pm 12^{\text {aby }}$ & $76 \pm 9^{\text {aby }}$ & $51 \pm 18^{\mathrm{bc}}$ & $35 \pm 9^{c}$ \\
\hline & Thick & $83 \pm 34^{\mathrm{c}}$ & $67 \pm 23^{c}$ & $117 \pm 33^{b x}$ & $156 \pm 21^{\mathrm{ax}}$ & $49 \pm 8^{\mathrm{d}}$ & $42 \pm 13^{\mathrm{d}}$ \\
\hline \multirow{2}{*}{ Gluconasturtiin } & Thin & $68 \pm 24^{\mathrm{ab}}$ & $49 \pm 12^{\text {by }}$ & $82 \pm 37^{\mathrm{a}}$ & $58 \pm 19^{\text {aby }}$ & $60 \pm 11^{\mathrm{ab}}$ & $44 \pm 19^{\text {by }}$ \\
\hline & Thick & $68 \pm 24$ & $77 \pm 13^{\mathrm{x}}$ & $80 \pm 28$ & $96 \pm 35^{\mathrm{x}}$ & $67 \pm 26$ & $58 \pm 22^{\mathrm{x}}$ \\
\hline \multirow{2}{*}{ Glucobrassicanapin } & Thin & $11 \pm 2^{\mathrm{a}}$ & $2 \pm 2^{\mathrm{dy}}$ & $5 \pm 2^{\text {cy }}$ & $8 \pm 2^{\text {by }}$ & $8 \pm 2^{\mathrm{b}}$ & $8 \pm 3^{b}$ \\
\hline & Thick & $11 \pm 2^{\mathrm{a}}$ & $7 \pm 2^{b x}$ & $13 \pm 6^{\mathrm{ax}}$ & $15 \pm 4^{\mathrm{ax}}$ & $7 \pm 2^{\mathrm{b}}$ & $7 \pm 2^{\mathrm{b}}$ \\
\hline \multirow{2}{*}{ 4-Hydroxy-glucobrassicin } & Thin & $8 \pm 3$ & $7 \pm 3^{b}$ & $9 \pm 1^{\mathrm{b}}$ & $11 \pm 3^{\mathrm{a}}$ & $7 \pm 2^{b}$ & $4 \pm 3^{\text {cy }}$ \\
\hline & Thick & $8 \pm 3$ & $10 \pm 3$ & $19 \pm 7$ & $14 \pm 4$ & $10 \pm 4$ & $13 \pm 9^{x}$ \\
\hline \multirow{2}{*}{ Glucoalyssin } & Thin & $6 \pm 3^{a}$ & $2 \pm 0^{b}$ & $5 \pm 2^{\text {ay }}$ & $7 \pm 2^{\text {ay }}$ & $4 \pm 2^{\mathrm{b}}$ & $3 \pm 1^{\mathrm{b}}$ \\
\hline & Thick & $6 \pm 3^{b}$ & $3 \pm 3^{b}$ & $12 \pm 7^{\mathrm{ax}}$ & $14 \pm 4^{\mathrm{ax}}$ & $2 \pm 1^{\mathrm{b}}$ & $4 \pm 2^{b}$ \\
\hline \multirow{2}{*}{ Progoitrin } & Thin & $6 \pm 5$ & $4 \pm 4$ & $4 \pm 7$ & $9 \pm 7$ & $9 \pm 8$ & $4 \pm 6$ \\
\hline & Thick & $6 \pm 5$ & $6 \pm 5$ & $12 \pm 4$ & $12 \pm 4$ & $14 \pm 7$ & $7 \pm 6$ \\
\hline \multirow{2}{*}{ Gluconapin } & Thin & $1 \pm 1$ & $0 \pm 0$ & $2 \pm 1$ & $2 \pm 2$ & $1 \pm 1$ & $1 \pm 1$ \\
\hline & Thick & $1 \pm 1$ & $0 \pm 0$ & $1 \pm 2$ & $0 \pm 1$ & $0 \pm 0$ & $0 \pm 0$ \\
\hline \multirow{2}{*}{ Gluconapoleiferin } & Thin & $0 \pm 0$ & $0 \pm 0$ & $0 \pm 0$ & $0 \pm 0$ & $0 \pm 0$ & $0 \pm 0$ \\
\hline & Thick & $0 \pm 0$ & $0 \pm 0$ & $0 \pm 0$ & $0 \pm 0$ & $0 \pm 0$ & $0 \pm 0$ \\
\hline \multirow{2}{*}{ Total } & Thin & $890 \pm 110^{a}$ & $454 \pm 100^{\mathrm{dy}}$ & $715 \pm 23^{\text {bcy }}$ & $819 \pm 36^{\text {aby }}$ & $595 \pm 67^{c}$ & $442 \pm 190^{\text {dy }}$ \\
\hline & Thick & $890 \pm 110$ & $890 \pm 210^{x}$ & $1090 \pm 290^{x}$ & $1330 \pm 320^{\mathrm{x}}$ & $925 \pm 270$ & $955 \pm 220^{x}$ \\
\hline
\end{tabular}

${ }^{\mathrm{e}}$ Content expressed as means \pm standard deviation. Means with different letters within a row (a, b, $c$, d) differ significantly $(p \leq 0.05$; significance of difference between measuring times). Means with different letters within a column ( $\mathrm{x}, \mathrm{y})$ differ significantly $(p \leq 0.05$; significance of difference between shredding types). Thin, $0.5 \mathrm{~mm}$ slices; thick, $2 \mathrm{~mm}$ slices.

at $20^{\circ} \mathrm{C}$ (Table 2), $25 \%$ for thin shredding at $8^{\circ} \mathrm{C}$, and $43 \%$ for thick shredding at $8^{\circ} \mathrm{C}$ (Table 1). The changes in the total GLS content were less pronounced during further storage up to $27 \mathrm{~h}$. At the end of the incubation, a statistically significant decrease was only seen for the thin shredded cabbage at $20^{\circ} \mathrm{C}$.

The three major glucosinolates, glucobrassicin, neoglucobrassicin, and sinigrin, accounted for more than $85 \%$ of the total GLS under all of the conditions analysed. Their contributions to the pool of total GLS changed as a result of the mechanical stress. Under all four processing and storage conditions, the relative proportion of neoglucobrassicin had already decreased 5 min after shredding. On the contrary, the relative proportion of glucobrassicin increased. Further storage at $8^{\circ} \mathrm{C}$ did not have a significant influence, whereas at $20^{\circ} \mathrm{C}$ a decrease in the relative proportion of glucobrassicin was observed, accompanied by an increase in neoglucobrassicin, for the thin and thick shredded cabbage after $27 \mathrm{~h}$ (Table 3).

Analysis of the data presented in Tables 1 and 2 reveals the great complexity in the GLS transformation that was induced by the mechanical stress. The extensive tissue damage caused by the thin shredding was reflected in an immediate decrease in GLS content at $20^{\circ} \mathrm{C}$. Disruption of GLS-containing Scells and myrosinase-containing M-cells will result in colocalisation of this enzyme and its substrates, which leads to
TABLE 3: Changes in the contents of the main GLS after $27 \mathrm{~h}$ storage, in comparison to unshredded cabbage.

$$
\text { Change (\%) }
$$

Glucosinolates

Shredding/storage temperature Thin $/ 8^{\circ} \mathrm{C}$ Thick $/ 8^{\circ} \mathrm{C}$ Thin $/ 20^{\circ} \mathrm{C}$ Thick $/ 20^{\circ} \mathrm{C}$

\begin{tabular}{lcccc}
\hline Glucobrassicin & +23 & $+55^{* * a}$ & $-24^{*}$ & $+38^{*}$ \\
Neoglucobrassicin & $-33^{* * *}$ & -12 & $-58^{* * *}$ & $-21^{*}$ \\
Sinigrin & $+36^{*}$ & $+70^{* *}$ & $-40^{* *}$ & -2 \\
Total & +14 & $+40^{* * *}$ & $-34^{* * *}$ & +16
\end{tabular}

${ }^{a}$ Levels of significance: statistically significant: ${ }^{*} p \leq 0.05$ and ${ }^{* *} p \leq 0.01$; highly statistically significant: ${ }^{* * *} p \leq 0.001$.

substrate hydrolysis [26]. The decrease in GLS content that was observed only at $20^{\circ} \mathrm{C}$ can be attributed to a higher reaction rate, which is typically more than doubled when the temperature is increased by $10^{\circ} \mathrm{C}$ within this temperature range.

There have been various studies on the influence of mechanical stress on GLS content during prolonged storage of Brassicaceae [15, 16, 27, 28]. Those studies were performed on relatively large time scales, with the first measurements 
typically determined only the day after the processing. However, these data have been controversial, as both increases and decreases in GLS have been reported. The influences of biotic and abiotic stress on the induction of enzymes and other proteins involved in GLS biosynthesis at the DNA level are well documented [29], and these can explain the accumulation of GLS that has been observed in some studies. In the present study, we analysed the changes in GLS content immediately after processing and the increase observed within a $30 \mathrm{~min}$ period, under all four processing and storage conditions. However, at these shorter times, the mechanisms of enzyme induction cannot explain the effects, as the time is too short, and thus other mechanisms must be involved.

The key step in GLS biosynthesis is the formation of aldoximes from their precursor amino acids [30]. Mechanical stress results in accumulation of reactive oxygen species and an increase in $\mathrm{H}_{2} \mathrm{O}_{2}$ levels [31]. The enzyme that catalyses the conversion of tryptophan into indole-3-acetaldoxime, the precursor of indole glucosides, is peroxidase, which is stimulated by $\mathrm{H}_{2} \mathrm{O}_{2}$ [32]. The pool of precursor free amino acids in Brassicaceae such as broccoli and white cabbage is relatively small, although they are sufficient to compensate for the loss of GLS by hydrolysis $[33,34]$. However, the content of neoglucobrassicin formed by a secondary modification of glucobrassicin is not increased in line with this hypothesis. Thick shredding resulted in higher GLS content at both temperatures. Under these conditions, fewer cells were disrupted, and accordingly biosynthesis prevailed over GLS hydrolysis.

\section{Conclusions}

It appears obvious that the shredding intensity has a large influence on GLS content immediately after the processing of white cabbage. Intensive tissue damage at $20^{\circ} \mathrm{C}$ results in a lower GLS content, whereas mild processing at $8^{\circ} \mathrm{C}$ results in the accumulation of GLS even only 5 min after shredding. Further storage for up to $30 \mathrm{~min}$ resulted in the accumulation of GLS in comparison to the GLS content after $5 \mathrm{~min}$, for all of these processing conditions. The observed increase in GLS content was within a timescale that is too short to be explained by enzyme biosynthesis at the DNA level. The relative proportions of the two major glucosinolates, neoglucobrassicin and glucobrassicin, were also changed after shredding, in favour of higher glucobrassicin levels.

\section{Conflict of Interests}

The authors declare that there is no conflict of interests regarding the publication of this paper.

\section{References}

[1] D. Rico, A. B. Martín-Diana, J. M. Barat, and C. Barry-Ryan, "Extending and measuring the quality of fresh-cut fruit and vegetables: a review," Trends in Food Science \& Technology, vol. 18, no. 7, pp. 373-386, 2007.

[2] F. Nassivera and S. Sillani, "Consumer perceptions and motivations in choice of minimally processed vegetables: a case study in Italy," British Food Journal, vol. 117, no. 3, pp. 970-986, 2015.
[3] M. E. Guerzoni, A. Gianotti, M. R. Corbo, and M. Sinigaglia, "Shelf-life modelling for fresh-cut vegetables," Postharvest Biology and Technology, vol. 9, no. 2, pp. 195-207, 1996.

[4] V. Cliffe-Byrnes and D. O'Beirne, “The effects of cultivar and physiological age on quality and shelf-life of coleslaw mix packaged in modified atmospheres," International Journal of Food Science \& Technology, vol. 40, no. 2, pp. 165-175, 2005.

[5] I. Pasha, F. Saeed, M. T. Sultan, M. R. Khan, and M. Rohi, "Recent developments in minimal processing: a tool to retain nutritional quality of food," Critical Reviews in Food Science and Nutrition, vol. 54, no. 3, pp. 340-351, 2014.

[6] L. F. Reyes, J. E. Villarreal, and L. Cisneros-Zevallos, "The increase in antioxidant capacity after wounding depends on the type of fruit or vegetable tissue," Food Chemistry, vol. 101, no. 3, pp. 1254-1262, 2007.

[7] A. M. Bones and J. T. Rossiter, "The enzymic and chemically induced decomposition of glucosinolates," Phytochemistry, vol. 67, no. 11, pp. 1053-1067, 2006.

[8] M. Ishida, M. Hara, N. Fukino, T. Kakizaki, and Y. Morimitsu, "Glucosinolate metabolism, functionality and breeding for the improvement of brassicaceae vegetables," Breeding Science, vol. 64, no. 1, pp. 48-59, 2014.

[9] K. F. M.-J. Tierens, B. P. H. J. Thomma, M. Brouwer et al., "Study of the role of antimicrobial glucosinolate-derived isothiocyanates in resistance of Arabidopsis to microbial pathogens," Plant Physiology, vol. 125, no. 4, pp. 1688-1699, 2001.

[10] D. J. Kliebenstein, J. Kroymann, and T. Mitchell-Olds, "The glucosinolate-myrosinase system in an ecological and evolutionary context," Current Opinion in Plant Biology, vol. 8, no. 3, pp. 264271, 2005.

[11] D. W. Griffiths, A. N. E. Birch, and J. R. Hillman, "Antinutritional compounds in the Brassicaceae. Analysis, biosynthesis, chemistry and dietary effects," Journal of Horticultural Science and Biotechnology, vol. 73, no. 1, pp. 1-18, 1998.

[12] C. A. Thomson and T. L. Green, "Cruciferous vegetables and cancer prevention," in Functional Foods and Nutraceuticals in Cancer Prevention, R. R. Watson, Ed., pp. 263-286, Iowa State Press, Ames, Iowa, USA, 2003.

[13] D. A. Moreno, M. Carvajal, C. López-Berenguer, and C. GarcíaViguera, "Chemical and biological characterisation of nutraceutical compounds of broccoli," Journal of Pharmaceutical and Biomedical Analysis, vol. 41, no. 5, pp. 1508-1522, 2006.

[14] J. R. Devi and E. B. Thangam, "Mechanisms of anticancer activity of sulforaphane from Brassica oleracea in HEp-2 human epithelial carcinoma cell line," Asian Pacific Journal of Cancer Prevention, vol. 13, no. 5, pp. 2095-2100, 2012.

[15] I. Mewis, H. M. Appel, A. Hom, R. Raina, and J. C. Schultz, "Major signaling pathways modulate Arabidopsis glucosinolate accumulation and response to both phloem-feeding and chewing insects," Plant Physiology, vol. 138, no. 2, pp. 1149-1162, 2005.

[16] R. Verkerk, M. Dekker, and W. M. F. Jongen, "Post-harvest increase of indolyl glucosinolates in response to chopping and storage of Brassica vegetables," Journal of the Science of Food and Agriculture, vol. 81, no. 9, pp. 953-958, 2001.

[17] M. Wennberg, J. Ekvall, K. Olsson, and M. Nyman, "Changes in carbohydrate and glucosinolate composition in white cabbage (Brassica oleracea var. capitata) during blanching and treatment with acetic acid," Food Chemistry, vol. 95, no. 2, pp. 226-236, 2006. 
[18] V. Rungapamestry, A. J. Duncan, Z. Fuller, and B. Ratcliffe, "Changes in glucosinolate concentrations, myrosinase activity, and production of metabolites of glucosinolates in cabbage (Brassica oleracea var. capitata) cooked for different durations," Journal of Agricultural and Food Chemistry, vol. 54, no. 20, pp. 7628-7634, 2006.

[19] M. M. Kushad, A. F. Brown, A. C. Kurilich et al., "Variation of glucosinolates in vegetable crops of Brassica oleracea," Journal of Agricultural and Food Chemistry, vol. 47, no. 4, pp. 1541-1548, 1999.

[20] J. Nilsson, K. Olsson, G. Engqvist et al., "Variation in the content of glucosinolates, hydroxycinnamic acids, carotenoids, total antioxidant capacity and low-molecular-weight carbohydrates in Brassica vegetables," Journal of the Science of Food and Agriculture, vol. 86, no. 4, pp. 528-538, 2006

[21] B. Kusznierewicz, A. Bartoszek, L. Wolska, J. Drzewiecki, S. Gorinstein, and J. Namieśnik, "Partial characterization of white cabbages (Brassica oleracea var. capitata f. alba) from different regions by glucosinolates, bioactive compounds, total antioxidant activities and proteins," LWT-Food Science and Technology, vol. 41, no. 1, pp. 1-9, 2008.

[22] J. Volden, T. Wicklund, R. Verkerk, and M. Dekker, "Kinetics of changes in glucosinolate concentrations during long-term cooking of white cabbage (Brassica oleracea L. ssp. capitata $\mathrm{f}$. alba)," Journal of Agricultural and Food Chemistry, vol. 56, no. 6, pp. 2068-2073, 2008.

[23] C. Martinez-Villaluenga, E. Peñas, J. Frias et al., "Influence of fermentation conditions on glucosinolates, ascorbigen, and ascorbic acid content in white cabbage (Brassica oleracea var. capitata cv. Taler) cultivated in different seasons," Journal of Food Science, vol. 74, no. 1, pp. C62-C67, 2009.

[24] E. Peñas, J. Frias, C. Martínez-Villaluenga, and C. VidalValverde, "Bioactive compounds, myrosinase activity, and antioxidant capacity of white cabbages grown in different locations of Spain," Journal of Agricultural and Food Chemistry, vol. 59, no. 8, pp. 3772-3779, 2011.

[25] T. Bohinc, M. Devetak, and S. Trdan, "Quantity of glucosinolates in 10 cabbage genotypes and their impact on the feeding of Mamestra brassicae caterpillars," Archives of Biological Sciences, vol. 66, no. 2, pp. 867-876, 2014.

[26] R. Kissen, J. T. Rossiter, and A. M. Bones, "The 'mustard oil bomb': not so easy to assemble?! Localization, expression and distribution of the components of the myrosinase enzyme system," Phytochemistry Reviews, vol. 8, no. 1, pp. 69-86, 2009.

[27] R. Verkerk, M. S. Van Der Gaag, M. Dekker, and W. M. F. Jongen, "Effects of processing conditions on glucosinolates in cruciferous vegetables," Cancer Letters, vol. 114, no. 1-2, pp. 193194, 1997.

[28] L. Song and P. J. Thornalley, "Effect of storage, processing and cooking on glucosinolate content of Brassica vegetables," Food and Chemical Toxicology, vol. 45, no. 2, pp. 216-224, 2007.

[29] I. E. Sønderby, F. Geu-Flores, and B. A. Halkier, "Biosynthesis of glucosinolates-gene discovery and beyond," Trends in Plant Science, vol. 15, no. 5, pp. 283-290, 2010.

[30] M. D. Mikkelsen, B. L. Petersen, C. E. Olsen, and B. A. Halkier, "Biosynthesis and metabolic engineering of glucosinolates," Amino Acids, vol. 22, no. 3, pp. 279-295, 2002.

[31] M. Orozco-Cardenas and C. A. Ryan, "Hydrogen peroxide is generated systemically in plant leaves by wounding and systemin via the octadecanoid pathway," Proceedings of the National Academy of Sciences of the United States of America, vol. 96, no. 11, pp. 6553-6557, 1999.
[32] J. Ludwig-Muller and W. Hilgenberg, "A plasma membranebound enzyme oxidizes L-tryptophan to indole-3-acetaldoxime," Physiologia Plantarum, vol. 74, no. 2, pp. 240-250, 1988.

[33] E. Rosa and M. Helena Gomes, "Relationship between free amino acids and glucosinolates in primary and secondary inflorescences of 11 broccoli (Brassica oleracea L var italica) cultivars grown in early and late seasons," Journal of the Science of Food and Agriculture, vol. 82, no. 1, pp. 61-64, 2002.

[34] A. P. Oliveira, D. M. Pereira, P. B. Andrade et al., "Free amino acids of tronchuda cabbage (Brassica oleracea L. Var. costata DC): influence of leaf position (internal or external) and collection time," Journal of Agricultural and Food Chemistry, vol. 56 , no. 13 , pp. 5216-5221, 2008. 

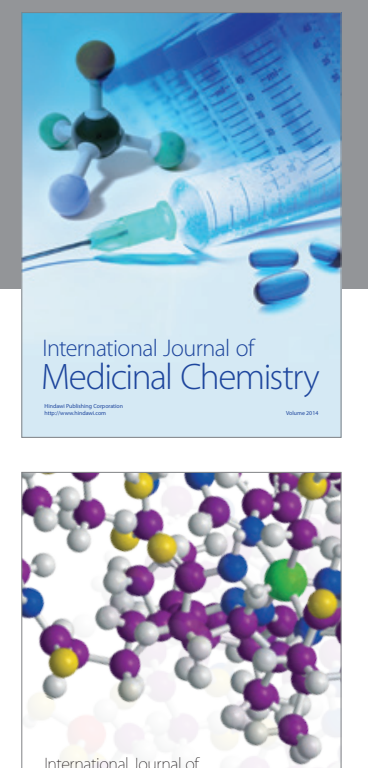

\section{Carbohydrate} Chemistry

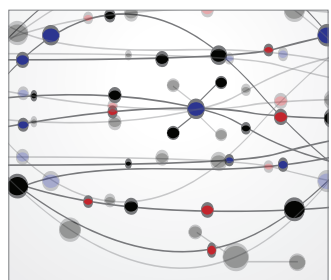

The Scientific World Journal
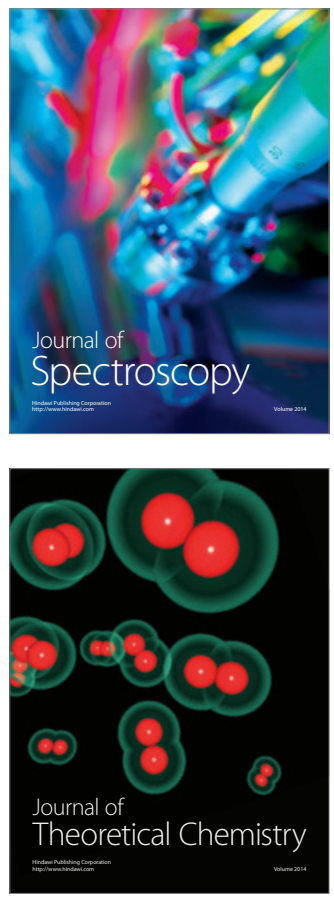
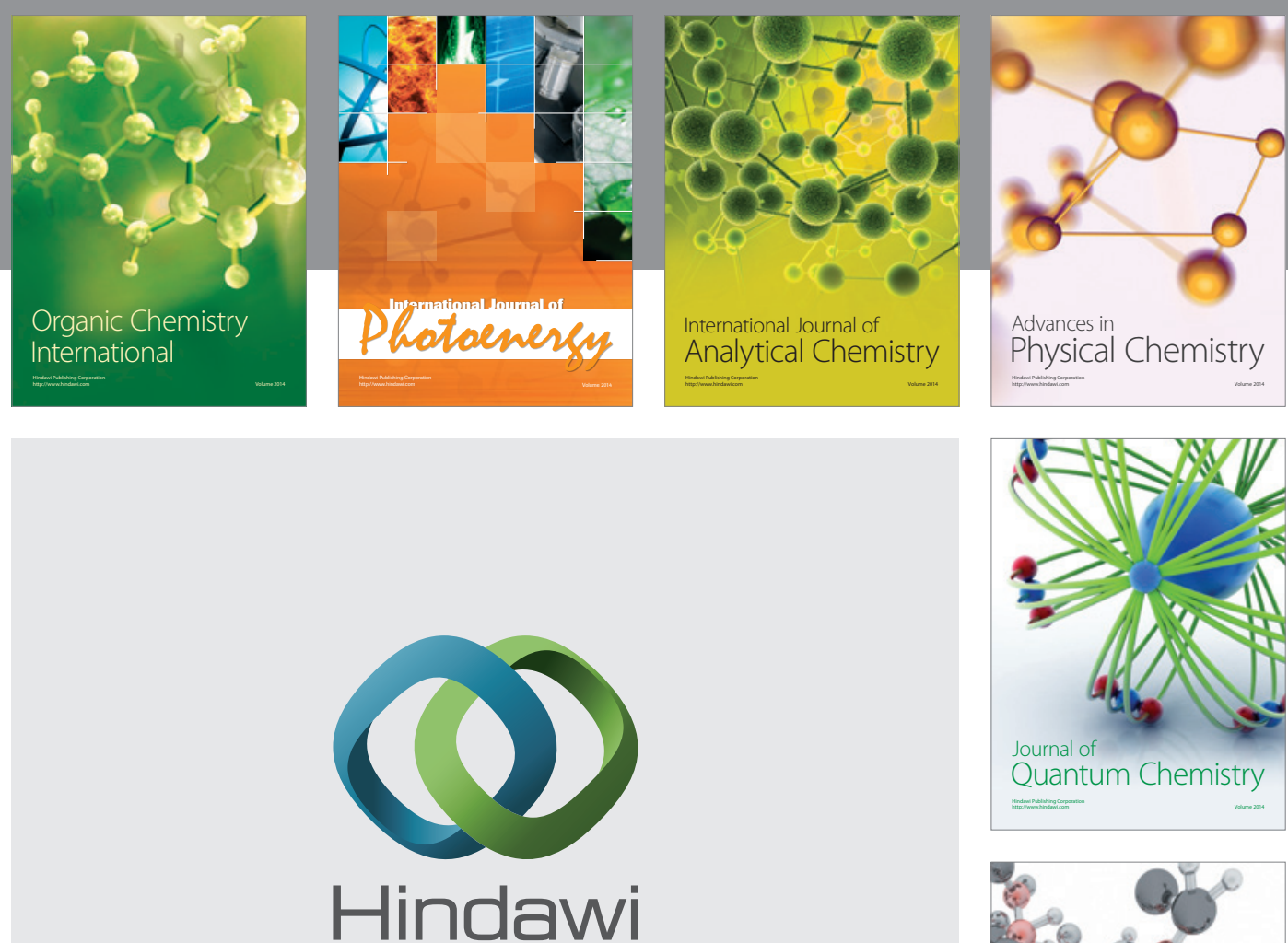

Submit your manuscripts at

http://www.hindawi.com

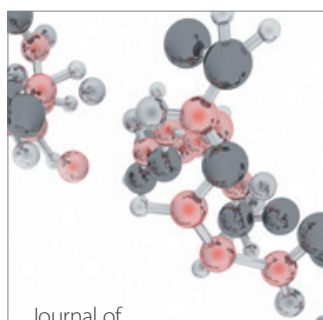

Analytical Methods

in Chemistry

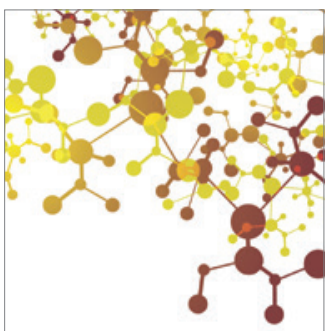

Journal of

Applied Chemistry

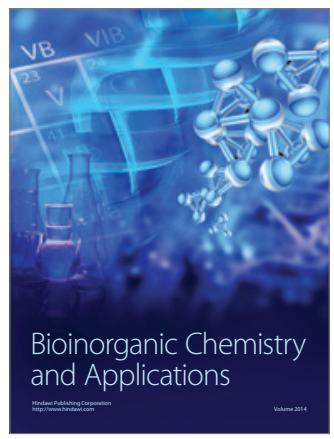

Inorganic Chemistry
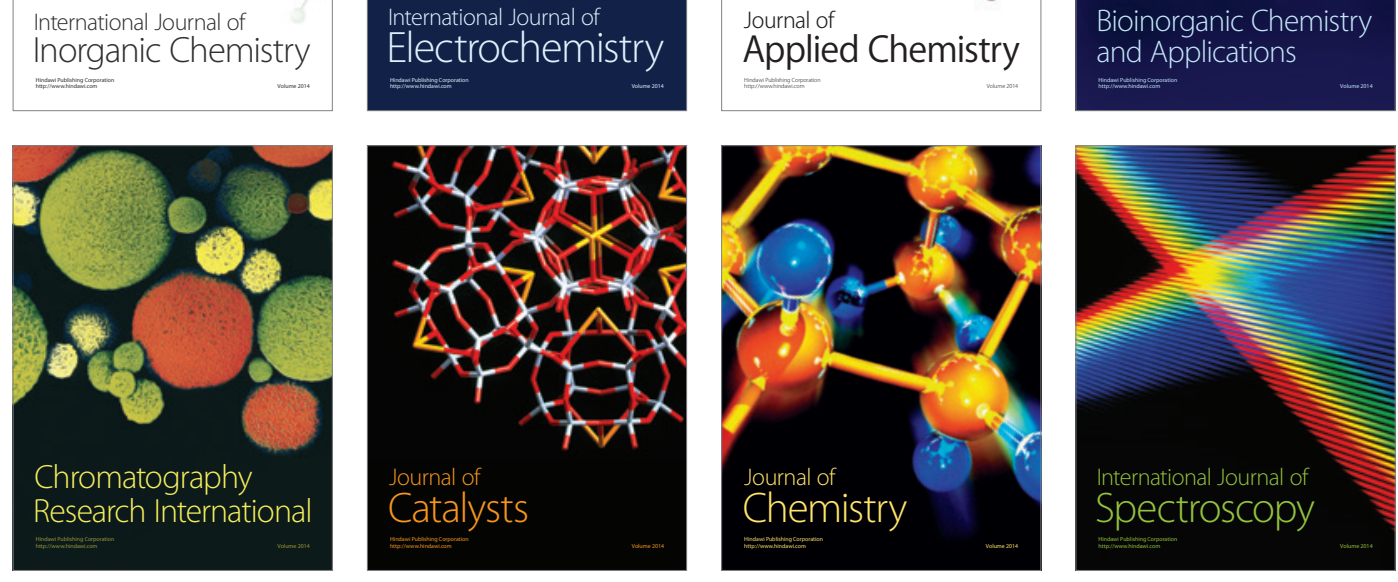